\title{
Legal framework for wildlife farming benefits species conservation and preventing wildlife crimes in Vietnam
}

\author{
Duc Hanh Nguyen ${ }^{1, *}$, and Thi Mai Dinh ${ }^{2}$ \\ ${ }^{1}$ Hanoi Procuratorate University (HPU), Duong Noi Street, No. 59/230 Y La, 1000, Hanoi, Viet Nam \\ ${ }^{2}$ Graduate Academy of Social Sciences, Nguyen Trai Street, No. 477, Thanh Xuan District, Ha Noi, \\ 10000, Vietnam
}

\begin{abstract}
Animal husbandry plays a certain role in economic growth of the agricultural sector. Compared with conventional husbandry, wildlife farming brings important, even many times greater economic benefits with certain species. At present, however, due to different objective and subjective factors, the raising of wild animals in Vietnam has not been adequately taken care of and faced several difficulties. The inadequate legal structure for wildlife farming has caused difficulties to farmers when finding breeding supplies and product output. In addition, wildlife criminals take advantage of agricultural operations to cover up their crimes, evade the detection and handle from the authorities. In order to contribute to promoting the development of agricultural economy in general, the economy of organizations and individuals participating in animal husbandry activities in particular, we aims at recognizing, examining and reviewing the existing legal system for wildlife-farming practices, crime situation and crime handling in Vietnam in recent years in this research. We will detect the difficulties, obstacles and inadequacies of the legal framework on wildlife farming, as well as the prevention and prosecution of wildlife crimes, propose strategies and guidelines for perfecting the law and appropriately implementing law provisions.
\end{abstract}

\section{Introduction}

Vietnam is considered to be one of the countries with a high level of biodiversity in the world. If thoroughly investigated, Vietnam can have up to 20,000 - 30,000 higher plant species, accounting for $6.5 \%$ of the world's total species [7]. In this country with natural characteristics of tropical and monsoon climate, people have recored 310 species of mammals, 840 species of birds, 296 species of reptiles, 162 species of amphibians, over 700 species of freshwater fish and about 2,000 species of sea fish, in addition to thousands of invertebrates living on land and underwater[14]. Therefore, in addition to the conventional species of livestock and poultry that are already part of the agricultural economic system of Vietnam, we can totally implement wildlife farming, including the vulnerable, precious and rare species, in natural and near-natural environments. In fact,

\footnotetext{
*Corresponding author: hanhtrangvnncs1@gmail.com
} 
such activities have appeared, but mainly on tiny and scale, without long-term steadiness and strict supervision. Vietnam's economy is still an underdeveloped agricultural one, with about 25 million people living on forest resources and 8 million people living on fishing. In addition, there are 12 million people whose regular income is from fishing [2]. People still preserve the common habit of using natural products like animals and plants to meet daily needs, to make medicines, etc. In addition to the natural and social factors that facilitate wildlife farming, there has also been an increase in wildlife crime. Criminals take advantage of these characteristics to conceal their crimes, leading to uncontrolled exploitation of natural resources, degradation of nature and environment. Therefore, further strengthening activities to prevent and combat wildlife crimes is essential.

In recent years, many wildlife-raising activities in Vietnam have been implemented for species such as porcupines, snakes, deer, crocodiles, tortoises, etc. This movement has brought about many times higher economic benefits than traditional animal husbandry or agricultural activities, both theoretically and practically. Propore wildlife farming is in line with the Convention on International Trade in Endangered Species of Wild Fauna and Flora (CITES) and other bilateral and multilateral international treaties signed by Vietnam. Refering to international legislation, Vietnam has established a legal structure and criminal code to regulate wildlife farming and trade practices related to wildlife products, as well as the system of administrative sanctions and other wildlife related legal framework such as: Law on Biodiversity, Law on Foresty, Law on Fisheries, Law on Animal Husbandry, Decree No. 160/2013/ND-CP dated November 12, 2013 of the Government on criteria to determine species and the regime of managing species under lists of endangered, precious and rare species prioritized protection, Decree No. 06/2019/ND-CP dated January 22, 2019 of the Government on management of endangered, precious and rare species of forest fauna and flora and observation of convention on international trade in endangered species of wild fauna and flora, Decree No. 35/2019/ND-CP dated April 25, 2019 of the Government stipulating penalties for administrative violations against regulations on forestry, Circular No. 29/2019/TT-BNNPTNT dated December 31, 2019 of the Ministry of Agriculture and Rural Development on handling of forest animals being exhibits and Articles 234, 244 of the 2015 Penal Code, etc. These legal documents inherited from previous legal documents and developed therefrom.

Though there has been a fairly comprehensive set of legal documents relating to management, administrative violations and criminal treatment, on the basis of acquirement and incorporation of international law, the violations and crimes related to wildlife in Vietnam in recent years is still complicated and occur with different characteristics, levels and scales. Many wildlife offenders use farming to cover up their offences, evade the law. Analysis, studies, analyzes and evaluations of violations and crimes in recent years indicate that a range of laws have proved to be ineffective, making it difficult to track and treat crimes, creating loopholes for offenders such as: Criminals take advantage of the loose wildlife farming regulations to hold captive wild animals from the wild; unlawfully hunting, capturing, rearing, storing, transporting and selling various types of endangered, valuable and rare wild animals, but with the amount below the extent of criminal liability. Criminals trafficking large quantities of wildlife products such as pangolin scales are still be able to avoid high criminal charges if arrested. In addition, there are many regulations that make it difficult for law enforcement agencies to handle violations and crimes such as: Some terms in legal documents are not clear enought to understand and manipulate. The handling of material evidence and criminalization of violations relating to wildlife hybrids of group IB and IIB or of species included in Appendices I, II and III of CITES, and a number of protocols for dealing with wildlife cases are incomplete and vague.

Evaluating the challenges, issues and inadequacies of the legal system for wildlife production, as well as addressing breaches of wildlife farming-related crimes and 
violations, the study offers two groups of approaches and proposals to strengthen the legal system and to coordinate law enforcement. Law improvement solutions are as below: Amendments to the Decree No. 06/2019/ND-CP dated January 22, 2019 of the Government on allowing export, import and re-export for commercial purposes of species in CITES Appendix I that have been bred, reared or cross bred, provided that they must be the second generation held captive; marking specimens bred for sale; supplement the concept of the term "primary commercial purpose"; unifying the list of wildlife species with the Decree No. 64/2019/ND-CP dated July 16, 2019 of the Government and moving towards merging these two Decrees; supplement regulations on sustainable exploitation of some wildlife species; Amendments to Article 106 of the Criminal Procedure Code, Article 47 of the Criminal Code on handling physical evidences being wild animals, parts of wild animals and documents related to isolation, quarantine, veterinary medicine for these subjects in criminal cases; amendment to the Criminal Code in the direction of criminalizing more criminal acts and clarifying the concept of the "Inseparable parts required for life"; Amendments to Decree No. 35/2019/ND-CP dated April 25, 2019, to unify the Penal Code and administrative violations related to products of species of Group IB and CITES Appendix I valued at over VND 100,000,000; Solutions and recommendations in law implementation such as strengthening the capacity of law enforcement agencies, enhancing the incentive measures of wildlife husbandry for economical benefits; promoting the propagation and education to people, individuals and organizations participating in wildlife husbandry

\section{Material and Methods}

This study is based on:

- Analysis of documents, reports, data, situation of wildlife violations and crimes provided by state agencies and research agencies of Vietnam such as: Vietnam CITES Management Authority, the Ministry of Agriculture and Rural Development, Supreme People's Court of Vietnam, Supreme People's Procuracy of Vietnam, Hanoi Procuracy University, etc.

- The study used data in the Report on the situation of wildlife violations and law enforcement in Vietnam in the 2013 - 2017 period of the Wildlife Conservation Society, Wildlife Conservation Society Vietnam (WCS Vietnam); Report on Analysis of legal framework on preventing illegal wildlife trade in Vietnam by USAID project of the United States; Consultancy Report on Assessment of some environmental, economic and social impacts of wildlife trade policy in Vietnam by CITES Scientific Authority of Vietnam Centre for Natural Resources and Environment Studies, Vietnam National University, Hanoi, Vietnam CITES Management Authority, the Forest Protection Department and the Ministry of Agriculture and Rural Development; Report on summarizing the review of wildlife cases by Hanoi Procuracy University; Report on reviewing the handle of wildlife cases at the People's Procuracy of Hanoi Procuracy University, articles and research papers on related magazines and the Internet, etc.

- In 2016 and 2017, the research team of eigth members (including the author) from Hanoi Procuracy University reviewed 128 wildlife cases accepted and settled by the Procuracies in 34 provinces of Vietnam from January 1, 2012 to January 1, 2017. The team reviewed the documents and consulted experts, prosecutors and lawyers personally handling the cases to learn about the contents relevant to the criminal situation, case handling, challenges, problems and shortcomings in addressing wildlife crimes. 


\section{Wildlife husbandry is an economic instrument for replacing conventional farming in Vietnam}

\subsection{Some natural and social characteristics of Vietnam}

Vietnam has a natural area of about $331,688 \mathrm{~km} 2$, with a total coastline of $3,260 \mathrm{~km}$, a mainland length of $1,650 \mathrm{~km}$, and thousands of islands. Vietnam is situated in the tropical monsoon zone with an annual rainfall of about $2,000 \mathrm{~mm} /$ year, an annual humidity of about $84 \%$, temperature fluctuation amplitude from $5^{\circ} \mathrm{C}$ in the winter to $37^{\circ} \mathrm{C}$ in the summer [9]. Vietnam's forested area is $12,616,700$ hectares and forest coverage is $37 \%$. The natural and planted forest area is 10,283,173 hectares and 2,333,526 hectares respectively. The total wood reserve is 813.3 million $\mathrm{m}^{3}$ (wood reserve in natural forests accounts for $95 \%$ ) and about 8.5 billion bamboos. The total area of unused land is 6.76 million hectares. This is a great potential to realize the forest development goal [12]. Vietnam is considered to be one of the countries with a high level of biodiversity in the world. If thoroughly investigated, Vietnam can have up to 20,000 - 30,000 higher plant species, accounting for $6.5 \%$ of the world's total species [7]. Vietnam's flora is highly endemic. The number of endemic species accounts for about $33 \%$ of the plant species in northern Vietnam [12] and over $40 \%$ of the plant species nationwide. Currently, there are 11,458 species of animals, 21,017 species of plants and 3,000 species of microorganisms, 1,030 species of moss and 826 species of large mushrooms [2]. Over 6,000 plant species are used for food, medicine, animal feed, wood mining, extraction of essential oils, and materials among the species mentioned [2]. People have recored 310 species of mammals, 840 species of birds, 296 species of reptiles, 162 species of amphibians, over 700 species of freshwater fish and about 2,000 species of sea fish, in addition to thousands of invertebrates living on land and underwater [13]. Vietnam's fauna has many species, including many endemic ones with special economic and scientific values. In the 1990s, only in the Central region of Vietnam, five new large mammals were found and described, including shola (Pseudoryx nghetinhensis), giant muntjac (Muntiacus vuquangensis), Truong Son muntjac (M.truongsonensis), grey-shanked douc langur (Pygathrix cinereus) and striped rabbit (Nesolagus timminsi) [3][15][8][18]. Also in this period, a large number of birds, reptiles, frogs, fish and invertebrates have been described in Vietnam, including three new species of birds and six species of crabs. In 10 years (as of 2002), 13 new genera, 222 new species and 30 new subspecies of plant were described in Vietnam [2]. According to some assessments, Vietnam is home to $10 \%$ of the world's plant and animal species, of which $28 \%$ are mammals, $10 \%$ are birds, $21 \%$ are declining and endangered reptiles and amphibians. With the aforementioned natural conditions, in addition to the conventional species of livestock and poultry that are already part of the agricultural economic system of Vietnam, we can totally implement wildlife farming, including the vulnerable, precious and rare species, in natural environments. In fact, such activities have appeared, but mainly on tiny and scale, without long-term steadiness and strict supervision. A portion of the population has begun catching both lawfully and illegally in order to satisfy domestic and foreign demand. It is one of the main reasons for species population loss. Due to illegal hunting and trading, species diversity in Vietnam has been declining at a phenomenal rate in recent years. There were only 25 endangered animal species in Vietnam in 1996, but this figure had risen to 48 by 2014. Many species are at an alarming rate, facing the high risk of extinction such as Tonkin snub-nosed monkey (Rhinopithecus avunculus) with only about 190 individuals, Delacour's langur (Trachypithecus delacouri) with only about 100 individuals, and tiger with only five individuals left in nature[14]. Therefore, if species recovery measures are not taken in time, extinction as in the case of the Vietnamese Java rhinoceros (Rhinoceros sondaicus annamiticus) in 2010 will repeat itself for several other wildlife species. 
Vietnam's economy is still an underdeveloped agricultural one, with about 25 million people living on forest resources and 8 million people living on fishing. In addition, there are 12 million people whose regular income is from fishing [2]. Vietnam is one of the most densely populated countries in the world, with a total population of more than 84 million by 2017 , an average population density of 254 people $/ \mathrm{km}^{2}$ and a population growth rate of $1.7 \%$ [9]. People still preserve the common habit of using natural products like animals and plants to meet daily needs, especially those in mountainous, remote and economically difficult areas. Some species are considered medicinal products for treating and nourishing the body, so they are harvested from nature. The battle against wildlife crimes is therefore still challenging, because criminals can take advantage of this social aspect to make illicit profits.

\subsection{Wildlife farming activities in Vietnam have improved the economy in recent years}

Wildlife-raising activities in Vietnam have existed for a long time, especially in forestcovered and mountainous areas where ethnic minorities live. They serve domestication and reproduction purposes such as daily living activities, medicine-making and food sources. In addition, nationally-designated nature reserves, national forests, and several wildlife rescue centers run under governmental approval by foreign organizations have been rearing and reproducing endangered wildlife species. In addition, recently, the Government has allowed the establishment of a number of wildlife farms for commercial purposes. In recent years, wildlife husbandry in Vietnam has also achieved great benefits, providing a relatively higher income for farmers compared to raising purebred or conventional agricultural production.

To date, Vietnam has not conducted a comprehensive survey and evaluation study for wildlife husbandry. However, in 2014, through a cooperation agreement between the FAO Emergency Center for Transboundary Animal Diseases (ECTAD) - FAO Vietnam and Vietnam Administration of Forestry (VNFOREST) - Ministry of Agriculture and Development Rural Development (MARD), a pilot survey for wildlife farms was conducted by Provincial Forest Protection Department (PFPDs) in 12 Southern provinces and cities including Ba Ria-Vung Tau, Ben Tre, Binh Duong, Binh Phuoc, Binh Thuan, Dong Nai, Dong Thap, Lam Dong, Long An, Tay Ninh, Tien Giang and Ho Chi Minh City, and had some results as below [5]:

Data were collected from 4,099 active wildlife farms and 1,907 newly discontinued wildlife farms. There are 11,009 animal groups raised at active wildlife farms, which include 5,587 wildlife groups and 5,422 domesticated animal groups. A total of 1,554,488 animal individuals being raised at the surveyed facilities, including 1,216,773 wildlife individuals of 184 species and 5 orders.

The most common types of wildlife farms are porcupine farming (1,538 facilities with 25,467 heads), oriental ratsnake (699 facilities with 111,906 heads) and deer (524 facilities with 3,452 heads). The animal species with the highest total number of individuals raised were crocodile, tortoise and oriental ratsnake, with 574,612 individuals, equivalent to $47 \%$ of the total number.

Among surveyed wildlife species, there are 532,777 heads, equivalent to $44 \%$ of the total number, of 84 species included in the CITES list (Annexes I, II and III). According to the regulations of the Government of Vietnam, the aforementioned facilities raise 713,639 wildlife individuals, equivalent to $59 \%$ of the total surveyed animals, belonging to 91 species under management (IB, IIB of Decree No. 32 and common wildlife animal Circular No.47)

$76 \%$ of the surveyed wildlife farms (equivalent to 3,127 farms) have registered with the 
General Department of Forestry and most of the registerations were made between 20102013 (77\%). Out of 971 unregistered facilities, there are 829 facilities raising 93,199 animals under the Government's management. The animals raised the most in these unregistered facilities are porcupines, wild boars and red-necked hemorrhoids.

Out of 1,916 newly-discontinued wildlife farms, the previously raised animals were porcupine (924 establishments with 13,062 heads), crocodile (304 establishments with 41,768 heads), oriental ratsnake (191 establishments with 14,142 heads), and wild boars (188 establishments with 3,745 heads).

Most wildlife farms (95\%) raise one or two wildlife species. Only 17 facilities raise more than 10 species. $70 \%$ of wildlife farms also raise other domesticated animals, including dogs $(53.7 \%)$, chickens $(37.1 \%)$, cats $(9 \%)$, and pigs $(9 \%) .54 \%$ of these facilities raise one or two animal species, while $14.3 \%$ raise three or four at a time.

Some reptiles such as crocodiles, pythons and oriental ratsnake are very easy to breed in captivity conditions, with a total of 716,892 animals reproduced in 2013. Meanwhile, some mammals (such as tigers, lynx, bears) can also be reproduced, but it is difficult to get detailed information on the number of babies born. In certain wildlife farms, animals with a high risk of communicable diseases such as wild boar $(64 \%)$, porcupine $(50.9 \%)$, spotted palm civet (34.6\%) and long-tailed macaque (19.4\%) are reproducing relatively successfully.

\subsection{Economic benefits from wildlife husbandry in Vietnam}

Husbandry is increasingly becoming an significant part of the country's agricultural economic system and, in particular, of the localities. Husbandry plays an important role in providing a source of food to satisfy the rising demands of society not only in the country but also to meet the needs of exports. In addition to the traditional husbandry forms of domesticated cattle and poultry, the raising of wild animals has brought high economic benefits and prenvented exhausting these resources in the wild.

Surveys in the provinces of the Red River Delta, North Central Coast and the Mekong River Delta show that wildlife-raising households has achieved higher economic efficiency than those producing other crops and livestock. Softshell turtle farming in the Red River Delta can provide many times greater benefits than rice, vegetable growing, or pig and cow rearing. Even, snake-raising revenue is 3-5 times higher than rice and vegetables cultivation, and ten times higher than that of pig and cow rearing. In the North Central provinces, raising deer also bring higher income than raising chickens and 5-10 times more than raising pigs. In the Mekong Delta, raising pythons and crocodiles bring major income, dozens of times higher than rice cultivation and hundreds of times higher than raising pigs. Breeding activities of some wildlife species have contributed significantly to the income structure of households and localities. Farming activities have also contributed significantly to poverty reduction and job creation for farmers in many areas [17].

The reason for high economic value of wildlife farming is the law of supply. An increase in price results in an increase in quantity supplied, and vice versa. In other words, quantities respond in the same direction as price changes. However, in reality, there are some supply curves that depend not only on the endogenous and exogenous factors of the normal supply function (prices of inputs and outputs, production techniques, number of suppliers, macroeconomic policies of the Government), but also depend on factors such as social psychology and biological factors of species (supply of plants and animals in the short term). The bio-economic model in the exploitation of endangered wildlife is a typical example of this statement. 


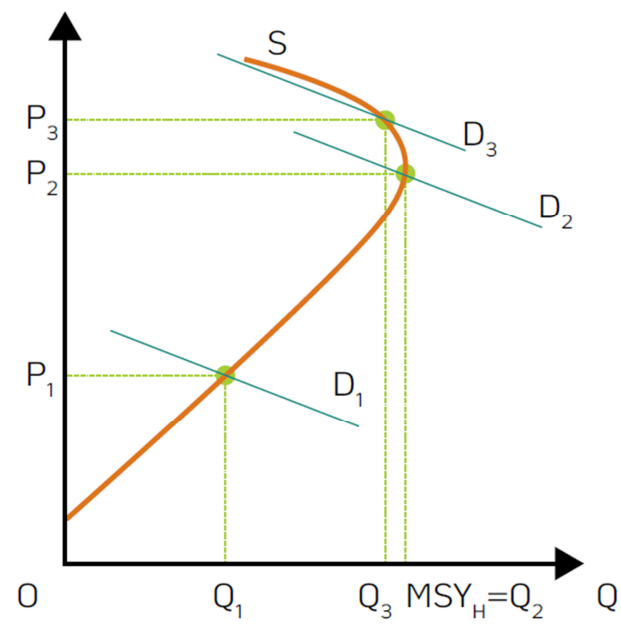

Fig. 1 Bio-economic model in the exploitation of endangered wildlife. Source: Nguyen Van Song (2009).

The bio-economic model of plants and animals exploitation shows that when the demand of society is low (D1), the market price will be P1 and the market supply will be Q1. When the market demand is D2, the market price will increase to P2 and the market supply will be Q2, which is equivalent to the maximum exploitable output (MSYH). Nevertheless, if the quantity demanded on the market increases to D3, which causes the market price to continue increasing to $\mathrm{P} 3$, the price and productivity of this form of resource is very high on the market, but the speed and reproductive capacity of these plant and animal species is limited (maximum at MSY). Therefore, the fact that species of plants and animals are being exhausted due to overexploitation will cause the supply curve (S) to curve backwards. At this time, the higher the price, the lower the supply. Due to great benefit, the exploitation is promoted while reserves is limited, preventing supply from meeting demand. The exploitation of the original resources make these plant and animal species increasingly scarce and at risk of extinction on global scale.

Research and practice have shown that the supply of wildlife, especially natural supply, is increasingly scarce while demand increases in the same direction as economic development and consumer income. This leads to an imbalance in supply and demand of wildlife animals, resulting in higher prices, bigger profits, and increased illegal trade.

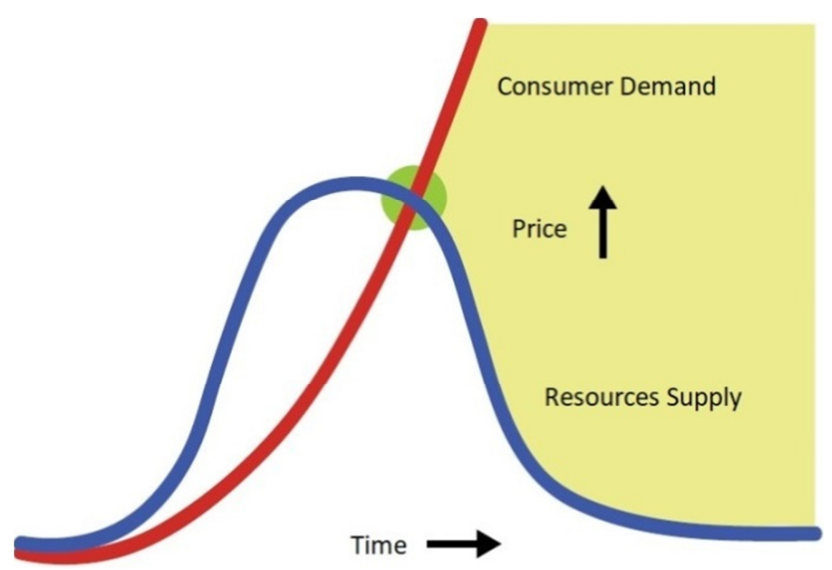

Fig. 2. Supply and demand of scarce resources (Source: http://bit.ly/btcs580). 


\section{International treaties signed by Vietnam and Vietnam's legal framework related to the management and handling of violations and crimes on wildlife}

\subsection{International treaties signed by Vietnam}

Species of wild fauna, including many endangered species, have always had a great impact on biodiversity. The disappearance of any species can cause ecological imbalance, adversely affecting our living environment, then it is required for all nations in the world to protect these species. However, this protection does not mean that the commercial exploitation of these species is prohibited. Protecting wildlife depends on the number of species, its geographic distribution, and conditions of wildlife farming under the Convention on International Trade in Endangered Species of Wild Fauna and Flora (CITES) on the scope, scale, and method of commercial exploitation of wildlife species agreed by many countries. On this Convention, it is required for the nations to be responsible for fulfilling the conditions when trading these species to protect them from being excessively exploited for commercial purposes. Vietnam became the $121^{\text {st }}$ Member State of CITES in 1994. The Convention is not aimed at banning the trade and farming of wild animals and plants, but it ensures these practices are sustainable. The country has been identified as one of the countries with full legal basis to implement CITES in accordance with its regulations. Therefore, there are registered wildlife farms for export purposes which are checked and supervised by competent authorities.

With the aim of fulfilling its international obligations in implementing CITES, Vietnam has issued legal documents on banning the import and export of endangered species listed in Appendix I to the Convention. The country has also signed a number of regional agreements and protocols designed to ensure international cooperation in this field. Currently, the legal framework of Vietnam for cooperation on the prevention of illegal wildlife trade is based on binding international agreements (United Nations Convention against Transnational Organized Crime - UNTOC, ASEAN Mutual Legal Assistance Treaty - ASEAN MLAT), and non-binding Memorandums of Understanding signed bilaterally with some countries (such as Laos, South Africa, Cambodia, Indonesia, and China). The UNTOC aims to strengthen the transnational cooperation against transnational organized crimes more effectively, and the United Nations Convention against Corruption (UNCAC) emphasizes the importance of international cooperation as a critical method to eliminate the enabling environment for criminals [16].

However, Vietnam shares the view of recognition that the international treaties do not provide a sufficient legal basis for international cooperation activities. It is only the MLAT that is effective enough to force law enforcement agencies to share/exchange information/evidence and participate in joint investigations in order to increase the effectiveness of the prosecution against illegal wildlife trade networks [27].

Vietnam has made an official statement that the provisions under the UNTOC and the UNCAC have no direct application. An international treaty is "directly applicable" in a country's legal system as the conclusion of the treaty comes into force automatically. An international treaty being not directly applicable means that the treaty has no legal value until the provisions on the internalization of that treaty are enacted [19].

Vietnam has stated that the implementation of the provisions of the UNTOC and UNCAC "must be consistent with the constitutional principles and governing laws of the Socialist Republic of Vietnam, based on the bilateral or multilateral cooperation agreements with other countries and the principle of reciprocity." In addition, "according to Article 16 of the UNTOC (on extradition), Vietnam has stated that it would not consider this 
Convention a direct legal basis for extradition. The Socialist Republic of Vietnam shall conduct extradition proceedings in accordance with the provisions of Vietnamese laws on the basis of extradition treaties and the principle of reciprocity."

In the context that the wildlife trade occurs at high levels between Africa and Asia, there is a need to enhance the cooperation between Vietnam and hotspot countries in Africa. On December 3, 2018, Vietnam and Mozambique signed the Mutual Legal Assistance Treaty, marking the first and only mutual legal assistance treaty between Vietnam and an African country.

\subsection{Vietnam's legal framework related to the management and handling of violations and crimes on wildlife}

- 2008 Law on Biodiversity stipulating regulations related to biodiversity, conservation and sustainable development;

- 2015 Law on Animal Health stipulating on prevention, treatment, and fighting against animal epidemics; quarantine of animals and animal products; control of animal slaughter, preliminary processing and processing of animals and animal products; inspection of veterinary hygiene; management of veterinary drugs; and veterinary practice;

- 2017 Law on Forestry stipulating mechanism for management, protection, development, and use of forests and forest resources under the supervision of the Ministry of Agriculture and Rural Development;

- 2017 Law on Fisheries stipulating management of fisheries activities, and rights and obligations of organizations and individuals involved in fisheries activities;

- 2018 Law on Animal Husbandry stipulating the State management of animal husbandry and activities of organizations and individuals in animal husbandry;

- Decree No. 160/2013/ND-CP dated November 12, 2013 (160/2013) of the Government on criteria for identifying species and management regime of species on the list of endangered, precious, and rare species prioritized for protection. The Decree also provides criteria for animal breeding and farming, and import and export of species prioritized for protection;

- Decree No. 06/2019/ND-CP dated January 22, 2019 (06/2019) of the Government on the management of endangered, precious, and rare forest plants and animals and implementation of the Convention on International Trade in Endangered Species of Wild Fauna and Flora;

- Decree No. 64/2019/ND-CP dated July 16, 2019 (64/2019) of the Government amending Article 7 of Decree No. 160/2013/ND-CP dated November 12, 2013 of the Government on criteria for determining species and management regime of species on the list of endangered, precious, and rare species prioritized for protection;

- Circular No. 04/2017/TT-BNNPTNT dated February 24, 2017 of the Ministry of Agriculture and Rural Development promulgating the list of species of wild fauna and flora specified in the annexes to the Convention on International Trade in Endangered Species of Wild Fauna and Flora;

- Decree No. 35/2019/ND-CP dated April 25, 2019 of the Government stipulating penalties for administrative violations arising in the forestry sector;

- Circular No. 29/2019/TT-BNNPTNT dated December 31, 2019 of the Ministry of Agriculture and Rural Development stipulating the handling of forest animals as exhibits/evidence and forest animals voluntarily handed over to the State by organizations and individuals;

- Decree No. 155/2016/ND-CP dated November 18, 2016 of the Government stipulating penalties for administrative violations against regulations on environmental protection;

- Decree No. 64/2018/ND-CP dated May 7, 2018 of the Government stipulating sanctions against administrative violations in the field of livestock breeds, animal feeds, and aquatic 
products;

- Decree No. 42/2019/ND-CP dated May 16, 2019 of the Government stipulating sanctions against administrative violations in the field of fisheries.

\subsection{Wildlife crimes in accordance with the law of Vietnam}

In the legislative history of Vietnam, there have been so far three Penal Codes developed in 1985, 1999 (amended 2009), and 2015 (amended 2017). All of these three Penal Codes stipulate regulations on handling wildlife-related violations to gradually perfect legislative techniques and promote the protection of these target groups:

- Article 181 on violations of regulations on forest management and protection under the 1985 Penal Code provided criminal penalties for violations of regulations on forest management and protection, causing serious, very serious or particularly serious consequences for birds and mammals. However, it did not detail which birds or animals were affected, the Penal Code, therefore, did not specify the handling of violations against aquatic species or reptiles. The Penal Code has also only handled the act of illegal wildlife poaching but has not yet handled the acts of illegal wildlife killing, captivity, transportation, possession and trade. There are only two structured penalty ranges with two types of penalties, including non-custodial reform of from one to three years or termed imprisonment from three months to 10 years.

- Article 190 on violations of regulations on the protection of precious and rare wildlife specified in the 1999 Penal Code (amended 2009), in which wild animals are identified as precious and rare species listed in two Governmental Decrees No. 32/2006/ND-CP and No. 160/2013/ND-CP. These species are under the group IB (part of Appendix I of CITES) and the group IIB (part of Appendix II of CITES). Due to the internalization of CITES, the condemnation of violations is not based on the severity of the consequences, but on the list of species from the Appendixes I and II of the Convention. The Penal Code provides for handling of four groups of violations which are illegal wildlife poaching, illegal wildlife killing, illegal wildlife transportation, and illegal wildlife trade. However, it has not applied criminal sanctions against the act of illegal wildlife possession yet, and the criminal legal entities have not been subject to those sanctions. Regarding the additional penalties, a fine from 50 million dongs to 500 million dongs has been added, and the penalty of termed imprisonment has been changed to between six months and seven years. The penalty of non-custodial reform of from one to three years has remained unchanged. According to the 1999 Penal Code, violations against wildlife individuals are penalized under the Article 190, while violations against body parts and products from wildlife were subject to penalties related to smuggling or illegal transportation of goods across borders or trade of prohibited goods under Articles 153, 154, and 155.

- The basic and comprehensive internalization of CITES has been shown in the 2015 Penal Code (amended 2017) with two important Articles to handle wildlife crimes, including Article 234 on violations of regulations on wildlife protection and Article 244 on violations of regulations on the protection of endangered, precious, and rare animals, with many changes as follows:

+ The subjects specified in the Article 234 are species of fauna listed in the Appendixes II and III of CITES and the subjects specified in the Article 244 are species of fauna listed in Appendix I of the Convention. However, among the species of fauna included in the Appendixes I and II, some have been given greater protection under the provisions of the Penal Code by the Government of Vietnam due to being listed in the groups IB and IIB under the Decrees No. 32/2006/ND-CP and 160/2013/ND-CP. If violations are made against these species, the quantitative levels of these violations to identify the corresponding penalties shall be lower than those of violations against other species listed 
in Appendixes I or II of CITES that are not included in the groups IB and IIB or are endangered, precious, and rare species prioritized for protection. The Decree No. 32/2006/ND-CP has been replaced by the Decree No. 06/2019/ND-CP dated January 22, 2019, and Article 7 on the list of species of the Decree No. 160/2013/ND-CP has been amended by the Decree No. 64/2019/ND-CP.

+ The 2015 Penal Code has included all acts of crimes defined in the 1999 Penal Code and has added the act of illegal wildlife possession. As cited in Articles 234 and 244, not only violations against wildlife individuals but also violations against inseparable body parts and products from wildlife are subject to penalties. In addition, for the Elephant Ivory and Rhino Horn, there are specific quantitative levels to identify the corresponding penalty range.

+ According to the two Articles, not only individuals but also legal entities are examined for criminal liability.

+ Regarding penalties, both Articles 234 and 244 stipulate five types of punishment, including three principal penalties of fine, non-custodial reform, and termed imprisonment and two additional penalties of ban from holding certain posts, practicing certain occupations or doing certain jobs. In particular, Article 234 stipulates fines of from 50 million dongs to 1.5 billion dongs and Article 244 stipulates fines of from 50 million dongs to two billion dongs. According to Article 234, the penalty of non-custodial reform of between six months and three years is applied, but this type of penalty is not prescribed in Article 244. Regarding the penalty of termed imprisonment, the duration of imprisonment as per Article 234 is between six months and three years and that as per Article 244 is between one and 15 years. For additional penalties of ban from holding certain posts, practicing certain occupations or doing certain jobs, the two Articles prescribe penalties of from one to five years.

- In order to understand and apply provisions of the Penal Code in dealing with wildlife crimes and overcoming a number of difficulties arising from practice, the Council of Judges of the Supreme People's Court has issued the Resolution No. 05/2018/NQ-HDTP dated November 5, 2018 guiding the application of the Article 234 on violations of regulations on wildlife protection and the Article 244 on violations of regulations on the protection of endangered, precious, and rare animals under the Penal Code.

\section{Offenses regarding wildlife in Vietnam during investigation and handling in recent year}

In recent years, Vietnam has become an important center regarding the trade, manufacture, and use of products made from while animals and plants in Southeast Asia [1]. According to statistics of Wildlife Conservation Society and WCS Vietnam, in 5 years from 2013 to 2017, Vietnam's law enforcement agencies had detected and apprehended 1,504 cases related to wildlife including illegal transportation, trade, capture, hunting, etc. of more than 180 species of wild animals. These cases were mostly made up of cases related to species of snakes $-20.55 \%(309 / 1,504)$, followed by turtles $-10.31 \%(155 / 1,504)$, birds $-8.58 \%$ $(129 / 1,504)$, pangolins $-7.38 \%(111 / 1,504)$, etc. The number of cases related to elephants and rhinos accounted for a small margin compared to the total number of wildlife-related cases apprehended and confiscated by Vietnam law enforcement agencies, sitting at $3.39 \% \%(51 / 1,504)$ and $2.73 \%(41 / 1,504)$, respectively. Recent years have seen Vietnam steadily becoming a deciding factor in apprehending, preventing, and cracking down on global wildlife criminals. The Government of Vietnam focused more on this matter, leading to the enhancement of the supervision over law enforcement agencies, appropriate adjustment to the Criminal Code, and deeper involvement in international cooperation. According to the principles of national sovereignty, the Vienna Convention on the Law of 
Treaties, of which Vietnam is a signatory, leaves open the possibility of maintain reservation for a treaty under the condition that the reservation must be in line with the country's object and purpose, Article 19 (c) of the Vienna Convention, 1969. Other signatories may also make statements (another form of reservation). Article 2(1)(d), the Vienna Convention in 1969. If the "statement" excludes or changes the validity of certain articles of a treaty when implemented in the mentioned country, it can be called a reservation.

People who commit offenses related to the exploitation of wildlife are identified as criminals by the Criminal Code and categorized into 03 main groups: (1) small and separated cases in which the criminals commit the crime to satisfy their needs or to serve the daily life of themselves or their family; (2) criminals who couldn't recognize that the animals they're trading, transporting, and caging are rare wildlife prioritized for protection; (3) Criminals who operate major animal trade and commit crimes for personal gains, often involve complex tricks to commit crimes and conceal criminals. They commit transnational crimes and organized crimes. Apart from crimes related to wildlife, they also commit other crimes such as money laundering, smuggling [20].

The review of 128 cases handled by legal proceeding authorities from January 1, 2020 to January 1, 2017 at 34 provinces nationwide showed that [21]:

- More than 40 exploited animal species included both aquatic and terrestrial animals. Many species were abused in large quantities. The abused species were whole individuals, animal parts or animal products. Among many prosecuting and investigating agencies, only 03 agencies directly prosecuted cases including the Police investigation agency (main investigation agency), Forest Rangers, Customs (conducting some of the investigations). The number of cases investigated and prosecuted by the Police was the highest $(83.6 \%)$, followed by the Forest rangers $(15.6 \%)$, and Customs with only 1 case $(0.8 \%)$.

- The majority of reviewed cases were timely handled per the law. However, there were 06 cases overdue and 02 exceeded the trial time limit. Out of the 128 collected cases, 80 cases requested the widening of the investigation but there were only 10 cases with the widened investigation.

- Regarding sentencing and punishment, a review of case files showed that the defendants were often sentenced per clause 1 or clause 2 of the corresponding offenses, mainly under Article 190 of the 1999 Penal Code (amended and supplemented in 2009). This is a less serious crime with a light punishment. The review showed that there were 34 cases in which the Court sentenced defendants to imprisonment, accounting for $33.33 \%$; the number of cases where the Court sentenced imprisonment but gave a suspended sentence to the defendants or applied other punishment without deprivation of freedom was 94, accounting for $66.67 \%$. The number of cases that the Court applied additional punishment was 14 , accounting for $13.72 \%$. Only 01 case was fined (instead of imprisonment).

- Regarding violations in the cases. Out of the reviewed 128 cases with 169 suspects, there were 4 groups of offenses: (i) hunting, (ii) trading, (iii) transportation and other violations. In particular, the most common violation of buying and selling accounted for $46.09 \%$, followed by transportation which accounted for $23.44 \%$, hunting accounted for $17.19 \%$, and the last was the storage and unknown violations which accounted for $13.28 \%$.

- According to Vietnamese law, commercial exploitation (e.g. processing and trading) species of Group IB, CITES' Appendix I and Species prioritized for protection are mostly prohibited. In the case of species belonging to Group IIB and CITES' Appendix II, these activities are limited. However, despite this public ban, some exceptions allow commercial exploitation under certain conditions. Although these exceptions may be relatively harmless at the macro level, they are closely related to the current illegal wildlife trade in Vietnam.

- Decree No. 06/2019/ND-CP dated January 1, 2019, of the Government permits the establishment of farms for wild animals and plants of CITES' Appendix I that were 
captured from the wild for commercial purposes. This is a problem because this regulation incentivizes and promotes the hunt of "breeding stock" from the wild to serve purposes of farming facilities ${ }^{2}$. Therefore, it's necessary to involve strict management and control from the authorities [22].

\section{Difficulties, shortcomings, and limits of the legal framework in wildife farming and the prevention and control of criminals related to wildlife}

Wildlife farming is very costly, effects of exploitation and production costs are most evident when a species is included in Appendix I of CITES, or the list of restricted exploitation and use according to the government's Decree because it leads to the partial or complete replacement of exploitation from the wild for business activities with artificial farming[17]. Farming requires certain costs of production investment and administrative procedures for these activities. These costs are often higher than the costs of exploiting from the wild, so many people tend to exploit from the wild then mix into the farmed products to carry out illegal trade. If it's left undetected and unhandled, it will create a cover for criminals to carry out their illegal activities. In fact, there have been cases of using zoos as cover and legalizing wildlife on farms [22].

Because the legal framework does not mention the management of species in the Appendix of CITES without natural habitats in Vietnam but are imported legally/illegally and currently existing on Vietnam territory in zoos, safari, farms [11].

Investigations and surveys at wildlife farming facilities in 12 provinces of southern Vietnam showed that the breeding of civets, primates, and pigs contains high risk in spreading animal-to-human diseases.

Disease map [5].

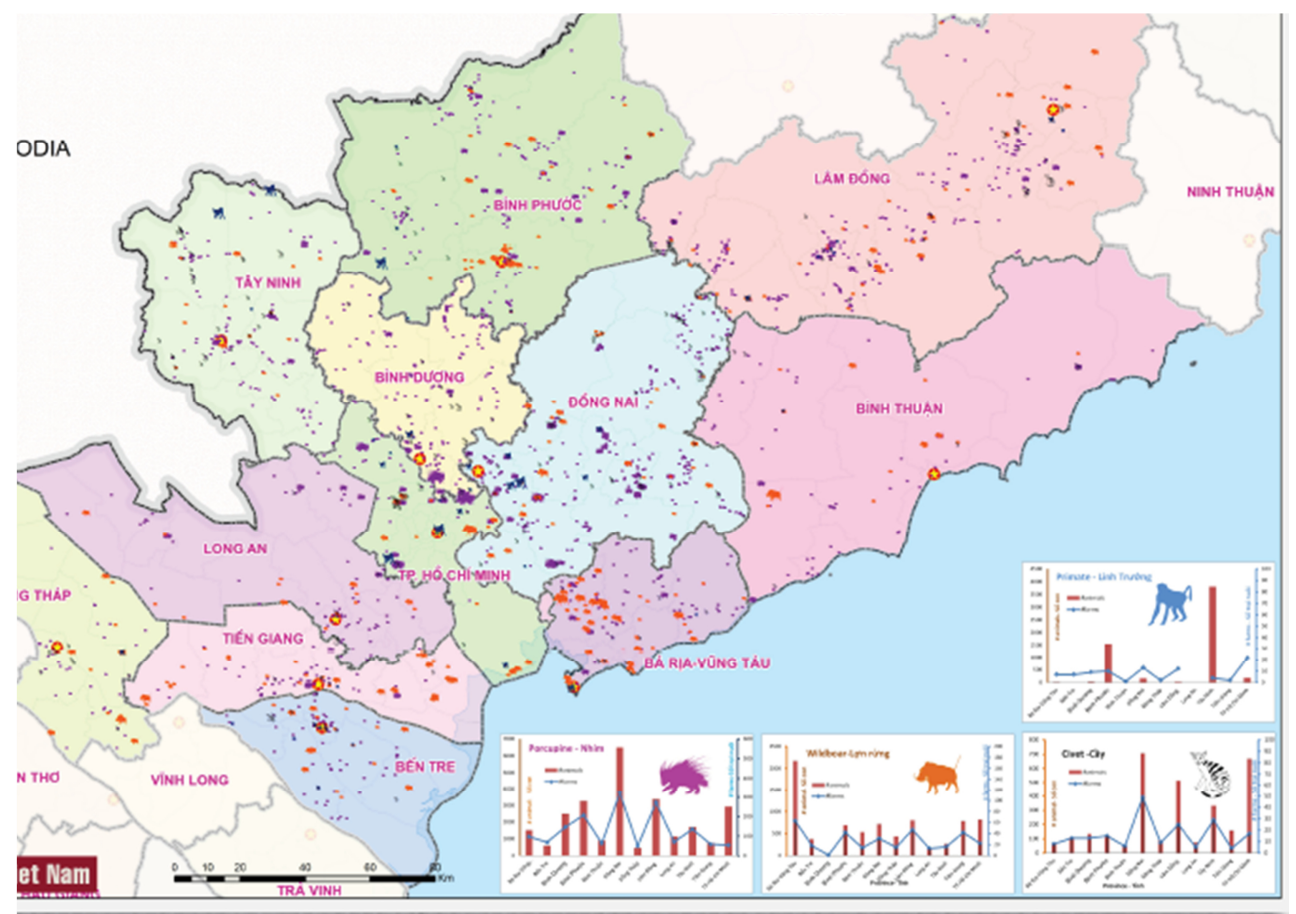

Fig. 3. Zoonotic disease risk map. 
Looking back at the recent history, pandemics in the last 20 years have shown an apparent connection to viral reservoirs in wildlife populations. The SARS epidemic in late 2002 and early 2003 which infected more than 8,000 people in 37 countries and resulted in 774 deaths originated from a new strain of betacorona virus. The virus originally came from bats and infected through an intermediate host called masked palm civet (Paguma larvata). The Middle East Respiratory Syndrome (MERS-CoV) which broke out in 2012, infected 2,494 people and killed 858 people also originated from another strain of coronavirus transmitted from camels to humans[22]. The African Swine Fever (ASF) which swept through China, Vietnam, and nine other countries and caused serious economic losses is thought to have originated from wild pigs in Africa[25]. By the end of 2019, all 63 provinces and cities of Vietnam were affected by ASF with over 5 million pigs culled. Scientific documents have indicated that the novel coronavirus originated from bats and was transmitted by an intermediary wildlife host to humans. Although this time the species that play as the intermediate host for transmitting the disease has not been determined, a research team in China thinks it may be pangolins. Regardless of which specific species, it can be said that wildlife trade is a cause of disease transmission through close contact between humans and wildlife. Therefore, illegal trading which is not under the control of the state and pandemic prevention and control authorities can pose a higher risk of spreading diseases. However, at the moment, the legal framework for disease control of farming activity is not sufficiently stringent and is not a compulsory condition to be implemented at the same time with another document for controlling commercial activities and trade licensing.

- Decree No. 06/2019/ND-CP dated January 22, 2019, listed "endangered, precious, and rare species prioritized for protection" including many species mentioned in the "list of endangered, precious and rare forest wildlife" of Decree No. 64/2019/ND-CP dated July 16, 2019, of the Government. The list included two categories: IB for endangered forest animals which are prohibited from commercial exploitation and use, and species listed in CITES' Appendix I that are naturally distributed in Vietnam; and IIB for non-endangered forest animals but will be endangered if not strictly managed or placed under restricted exploitation and use for commercial purposes and species listed in CITES' Appendix II that are naturally distributed in Vietnam.

- Decree No. 06/2019 permits the export, import, and re-export for commercial purposes of CITES' Appendix I species that have been bred, reared or cross-bred, provided that the animals are the second captive generation. The trade permission of the second generation of captive breeding species in CITES' Appendix I should be strictly regulated and monitored because of the risk of violations and the existence of the illegal farming industry with huge profits from endangered, precious and rare animals[26],[6]. Decree No. 06/2019 does not contain provisions for marking specimens of species included in CITES' Appendix I which are bred for sale (Report on Consultation and Assessment of Several Environmental, Economic, and Social Impacts of policy on Wild Flora and Fauna Trade in Vietnam, Vietnam). However, the recent Circular No. 27/2018 / TT-BNNPTNT dated November 16, 2018, and effective from January 1, 2019, contained provisions for the management and traceability of forest products including forest animals, especially the marking specimens of species in the list of endangered/precious forest animals and plants and the wild animal and plant species in CITES' Appendices[23]. Decree No. 06/2019 does not refer to the concept of 'primary commercial purposes' under the provisions of CITES, whereby all activities, whose non-commercial aspects are not particularly prominent, it should essentially be considered as primary commercial, and as a result, the import of specimens of Appendix I species will not be permitted[31]. Individuals or entities wishing to import specimens of Appendix I species are obligated to prove that the use of such specimens is entirely noncommercial. Under CITES, the term 'commercial purposes' should be defined by the 
importing country as broadly as possible so that any transaction that is not entirely 'noncommercial' will be considered as 'commercial'[24].

- The 2015 Criminal Code introduced the term "vital body part" which is a confusing and difficult term to apply, so Resolution No. 05/2018/NQ-HDTP dated November 5, 2018, provided guidelines in the application of some articles of the Criminal Code on Wildlife (Articles 234 and 244). The Resolution explained this term as: " Vital body parts mean animal body parts that have specialized functions. These parts right after being separated from the animal body will lead to the death of such animals (i.e.: head, heart, skin, skeleton, liver, etc.) ". However, taking parts of dead animals and committing the acts described in the criminal constitutions of Articles 234 and 244 will not be regarded as violations, as will the trafficking of vital body parts of animals belonging to group IB, CITES' Appendix I. In fact, it is extremely difficult to prove the "vital body parts" of wild-caught animals and farm animals of such species, creating loopholes for offenders to commit crimes. taking advantage by putting on the label of wild animals in captivity.

- Point b, Clause 1, Article 244 of the 2015 Criminal Code sanctioned violations of illegally storing, transporting and trading in "wildlife products" on the list of endangered, precious, rare and prioritized for protection species (species listed in Appendix I of Decree No. 64/2019/ND-CP). However, such activities offenses involving species of group IB (listed in Decree No.06/2019/ND-CP) and CITES' Appendix I, which does not coincide with the species listed in Appendix I of Decree No. 64/2019 / ND-CP, are not stipulated as violations. This is legally incomplete.

- Furthermore, in terms of fine, although Decree No. 35/2019 stipulated a fine of from VND 15,000,000 to VND 360,000,000 for products of species of Group IB or CITES' Appendix I, these penalties only apply to the illegal trade of products valued up to VND $100,000,000$ (Article 22.14.a and Article 23.14.a). There is no clear regulation on the illegal trade of products of species of Group IB or CITES' Appendix I valued at over VND $100,000,000$. How will the criminals be punished if these products are not in the scope of the Penal Code?

- Illegal hunting, capturing, killing, storing, transporting or trading of many different wildlife species included in CITES' Appendix I or Group IB but the number of individuals or vital body part is below the quantitative level to investigate for penal liability, the Criminal Code and guiding regulations that do not allow the accumulation of parts for handling also lead to criminals taking advantage of this loophole to carry out offenses.

- The 2015 Criminal Code does not distinguish the origin of wild animals in captivity and wild animals completely from nature to differentiate criminal liability. We think this is not logical because the dangerous nature of the behavior in these two cases is very different.

- The 2015 Criminal Code provided penalties for acts of infringing on species included in CITES' Appendix I, II, III of or Appendix IB and IIB prescribed in the Government's Decree but did not stipulate how to deal with animals bred between species in the appendices or these groups, making it difficult to handle in practice.

- In the handling of physical evidence of wild animals in group IB or CITES' Appendix I, there is no transfer to farming facilities in the form of providing breed stock, so the supplement this provision should be taken into consideration because it is not contrary to CITES regulations[17].

- For evidence that are wild animals seized in criminal cases, currently, Article 106 of the 2015 Criminal Code and Resolution No. 05/2018/NQ-HDTP of the Judges Council of the Supreme People's Court stipulate that the legal proceedings be handled by the procedure agencies and evidence shall be "handed over to the specialized management agency for handling" which are not the forms of evidence handling under Article 47 of the 2015 Penal Code[10]. This created an inconsistency in the law. Moreover, wildlife only handed over 
when results of the inspection come in, thus there are cases where these wild animals will become weak and die because it takes time from the moment of capturing to the inspection results. During this time, the conditions of captivity are not guaranteed, so the animals may no longer be worth to serve as breeding stock or suffer from lower survivability when released back into the wild.

\section{Recommendations for completing the legal framework and implementation of wild animal breeding practice and prevention of crimes involving wildlife}

\subsection{Completing the legal framework}

Complete the regulations on identifying and marking wildlife species, both those used for breeding and those acquired by reproduction, and use electric chips, codes, bar codes, etc., to differentiate them from those that are not acquired by breeding. Carry out the management and track the origin of forest products, assess the marking requirements of second-generation specimens that are bred for commercial purposes, adopt an appropriate supervising system, in which any exploitation without a licence and relevant documents will be considered illegal, and the owners of animal farms and breeding facilities are responsible for proving their origin. Amend the Decree No. 06/2019 so that species listed in Annex I of CITES can only be exploited from nature to serve the purpose of breeding and artificial reproduction, which are aimed towards science and preservation.

Supplement the Decree No. 06/2019 to specify that any wildlife species confiscated because of violating the Vietnamese law on wildlife must not be sold for commercial purposes, except for the purpose of breeding. For common wildlife and endangered, precious and rare species, the regulations on exploitation outside nature should be supplemented. Consider developing several models to manage the sustainable exploitation of some wildlife species for communities that depend heavily on natural resources, for example, the fishing community. National parks, nature reserves, and rescue centers can be potential places to sustainably develop and manage such models[17].

Propose simpler and more consistent regulations on forest and aquatic wildlife, which defines List I as species that decline significantly in number due to illegal exploitation and trafficking and need serious protection; List II as species whose quantity declines less significantly than List I and of which the exploitation and trade should be controlled; List III as species which are in good reproductive condition and whose breeding need to be promoted to boost the economic income. The enactment of lists of species that are under threat and need supervision should be agreed beforehand to avoid the duplication among decrees. Apart from scientific names of animals, the lists should include their Vietnamese names, common names, and areas of residence to make them familiar and understandable to farm owners and locals, which helps to mitigate the difficulty while implementing the decrees and avoid the situation of violating the law without being aware of it.

Prohibit all forms of exploitation and commercial exchanges of species in Group I and Annex I of CITES, except those that are second-generation breedings, and only allow the commercial exploitation of species in Group II and Annex II and III of CITES if there is the supervision of the State's agencies;

Implement an overall review to ensure the consistency and address the duplication among the provisions in the 2008 Law on Biodiversity, the 2015 Law on Veterinary Medicine, the 2017 Law on Forestry, the 2017 Law on Fisheries, the 2018 Law on Animal Husbandry, and relevant implementation documents so that the List of species that need prioritized protection is in line with the List of endangered, precious and rare species. 
Species stated in the List of prioritized protection should be the same as those mentioned in Group IB of the List of endangered, precious and rare species;

Promulgate a legal document that consolidates the provisions on preservation and breeding wild animals mentioned in the Law on Forestry, Law on Biodiversity, and Law on Environmental Protection. It is recommended to have a new decree that covers and unifies the contents of Decree No.06/2019, Decree No. 160/2013, and Decree No. 64/2019 of the Government. A new decree should also be promulgated to ensure the consistency in handling administrative violations committed by subjects specified in Decree No. 35/2019 and Decree No. 155/2016 of the Government;

Amend the 2015 Criminal Procedure Code's provision on handling wild animals which are confiscated and pieces of evidence that are wild animals. In particular, Article 106 of the current Criminal Procedure Code should be amended, mentioning "products of wild animals" to totally cover all types of evidence derived from wild animals and a document should be issued to guide the handling of wild animals and products derived from them that are confiscated during criminal cases, including the procedures for quarantine and veterinary inspection to ensure the animals' health after confiscation and before the release of examination results (before handing to the competent specialized control units). A list of specialized control units should be made.

Criminalize the acts of hunting, capturing, breeding, killing, keeping, transporting, and trafficking wild animals which are cross-bred between species mentioned in Group IB and IIB according to the Decree of the Government or Annex I, II, and III of CITES as soon as possible.

Criminalize the acts of storing, transporting, and trafficking the "products" derived from wild animals specified in Group IB and Annex I of CITES but not endangered, precious, and rare species that need prioritized protection.

Amend the Decree No. 35/2019/ND-CP dated April 25th, 2019, to be in line with the Penal Code's provision on administrative violations involving products derived from animals in Group B and in Annex I of CITES whose values are above 100,000,000 VND.

The Council of Judges continues to provide guidance to clarify the regulations on the cases of capturing a mixture of species in Group IB or Annex I of CITES which belong to different biological classes, but the number of species in each class is lower than the number stipulated in Clause 1, Article 244 of the Penal Code.

\subsection{Implementation and following the regulations of the law}

Establish and implement the mechanism to strengthen the cross-sectoral cooperation in preventing, investigating, and handling the acts of hunting, using, transporting, and trafficking wildlife (both flora and fauna), including the compulsory and feasible obligations to facilitate the cooperation;

Establish a cross-sectoral task force to assume the main responsibility for managing laws on wildlife or merging them into one sector instead of many sectors as currently. This will facilitate the effective use of resources and eliminate difficulties resulting from separate management systems. This cross-sectoral task force should be given the authority to manage protected species, export/import and license those that are used for breeding and rearing, report and assess protected species.

Have a correct point of view on the occupation of wildlife breeding, because if wellmanaged, this sector will bring about considerable economic benefits for people living in remote and mountainous areas and islands. Develop a favorable mechanism for the transport and consumption of bred wild animals to promote the growth of production.

Well-conduct the training for agriculture-promote and veterinary workers in preventing and addressing diseases from wildlife, absolutely avoid the transmission to human, ensure 
the safety for breeders and community, well-manage the pedigree of the bred animals, welldevelop the scale of breeding and selecting. Special attention should be paid to developing breeding practices in buffer zones around nature reserves, national parks, and eco-tourism parks.

Establish centers that provide sources for breeding facilities to minimize the number of facilities owning wild animals, which may be taken advantage of to hide criminal acts.

Improve the procedural authorities' capabilities of law enforcement and proactive detection of offenders committing acts violating laws on wildlife and strictly sanction them if detected.

Promote propaganda activities to raise public awareness of legal and illegal acts of breeding wild animals, therefore, they can develop their economic status in an appropriate manner without violating the law or supporting criminals.

Integrate wildlife breeding into other economic models, such as eco-tourism and educational research, to increase the locals' income.

\section{References}

1. C.L. Anh, N.M. Ha, Report on Current Situation of Wildlife Trafficking and Management Solutions. Unpublished report of CITES Vietnam (2005)

2. World Bank, Vietnam Environment Monitor (2005)

3. V.V. Dung, P.M. Giao, N.N. Chinh, D. Tuoc, P. Arctander, J. MacKinnon, Nature 363, 443- 445 (1993)

4. V.V. Chi, T. Hop, Useful Plants in Vietnam (Education Publishing House, Vietnam, 2001)

5. FAO, Brief Report on the Pilot Update of Data on Wild Animal Breeding Facilities in Southern Vietnam (2014)

6. C. Fischer, Journal of Environmental Economics and Management 38 (2002) DOI: 10.1016/j.jeem.2003.12.003

7. B. Groombridge, Global Biodiversity: Status of the Earth's Living Resources (Chapman and Hall, London, 1992)

8. P.M. Giao, D. Tuoc, V.V. Dung, E.D. Wikramanayake, G. Amato. P. Arctander, J.R. MacKinnon, Animal Conservation 1(1), 61-68 (1998)

9. General Statistics Office of Vietnam, Statistical Yearbook of Vietnam $(2004,2005)$

10. N.D. Hanh, Journal of Court 23, 11-17 (2019)

11. N. Nga, D. Huong, PanNature 29-30(I-II), 23-29 (2018)

12. Ministry of Agriculture and Rural Development, Decision No. 1970/QĐ/BNN-KL-LN (Vietnam, 2006)

13. Pocs Tamas, Acta Acad. Paed. Agriensis 3, 395-452 (1965)

14. Ministry of Natural Resources and Environment, Report of the National Situation of the Environment (Vietnam, 2005)

15. Ministry of Natural Resources and Environment, Report of the National Situation of the Environment in the 2011-2015 period (Vietnam, 2015)

16. T. Nadler, F. Momberg, Nguyen Xuan Dang, Lormee, Vietnam Primate Conservation Status review 2002. Part 2: Leaf Monkeys (Fauna and Flora International and Frankfurt Zoological Society, Hanoi, 2003)

17. Association of Southeast Asian Nations (ASEAN), Handbook of International and Legal Cooperation in Prevention of Human Trafficking (Jakarta, ASEAN, 2010) 
18. N.V. Song, D.T. Diep, PanNature 29-30(I-II), 13-14 (2018)

19. A.K. Surridge, R.J. Timmins, G.M. Hewitt, D.J. Bell, Nature 400, 726 (1999)

20. WCS Vietnam, Summary Report on Law Violation and Enforcement on Wildlife in Vietnam 2013-2017 period (2018)

21. USAID GIG Project, Brief Report on Reviewing Results of Wildlife Cases (Hanoi Procuratorate University, Vietnam, 2016)

22. USAID GIG Project, Report on Reviewing Results of Wildlife Cases at the People's Procuracies (Hanoi Procuratorate University, Vietnam, 2018)

23. USAID, Report: Analyzing the Legal Framework on Prevention of Wildlife Trafficking in Vietnam (2019)

24. L. Quan, Labor Review 4 (2018)

25. R. Lu et al., The Lancet (2020) DOI: https://doi.org/10.1016/S0140-6736(20)30251-8

26. WCS, WWF, TRAFFIC, AnimalsAsia, FAUNA\&FLORA, An open letter to the Prime Minister (The Lancet, Hanoi, 2020) DOI: https://doi.org/10.1016/S01406736(20)30251-8

27. Toolkit on analyzing criminals who violate laws of wildlife and forestry, Report of the UNDOC Delegation in Vietnam (UNDOC, UN, 2015) 